\title{
ВОЕННАЯ ПОВСЕДНЕВНОСТЬ
}

DOI: https://doi.org/10.15688/jvolsu4.2020.1.4

UDC 94(47)046

Submitted: 12.05.2019

LBC 63.3(2)4

Accepted: 21.11.2019

\section{“HIS WIFE HAS MARRIED...": TO THE PROBLEM OF THE FATE OF SOLDIERS' WIVES IN THE $17^{\text {th }}$ CENTURY}

\author{
Varvara G. Vovina-Lebedeva \\ Saint Petersburg Institute of History of the Russian Academy of Sciences, \\ Saint Petersburg, Russian Federation
}

\begin{abstract}
Introduction. The article deals with one important problem in the history of the $17^{\text {th }}$-century peasant family: the relationship between a woman and her family, as well as the family of her husband, in cases when this peasant was taken to military service for a long time. Methods and materials. The article is based on unpublished materials of the description of the Shenkurskaya and Podvinskaya chetverts of Vazhskiy uyezd in 1665. The author explores different situations of taking peasants in soldiers and further interaction of the volost with the families of these soldiers. The fates of soldiers' wives are a subject of special attention. Analysis and results. The paper considers various cases that are recorded in the census book: the case of soldier's wife living in the same yard with relatives of her husband or with her own relatives, the case of soldier's wife death, the case of "begging inside the parish". One of these variants was a new marriage of the soldier's wife. The cases when it took place after the death of the first husband were always recorded. We assume that numerous cases of women's marriage without remarks of her first husband's death reflect the practice of a cohabitation among the peasants, which was not consecrated by the church, but was actually recognized by the government and by volost residents.

Key words: Vazhskiy uyezd, taking in soldiers, census book, soldier's wife, volost, peasant family.

Citation. Vovina-Lebedeva V.G. "His Wife Has Married...": To the Problem of the Fate of Soldiers' Wives in the $17^{\text {th }}$ Century. Vestnik Volgogradskogo gosudarstvennogo universiteta. Seriya 4. Istoriya. Regionovedenie. Mezhdunarodnye otnosheniya [Science Journal of Volgograd State University. History. Area Studies. International Relations], 2020, vol. 25, no. 1, pp. 44-58. (in Russian). DOI: https://doi.org/10.15688/jvolsu4.2020.1.4
\end{abstract}

УДК 94(47)046

Дата поступления статьи: 12.05.2019

ББК $63.3(2) 4$

Дата принятия статьи: 21.11.2019

\section{«ЖЕНА ЕГО ВЫШЛА ЗАМУЖ...»: К ВОПРОСУ О СУДЬБАХ СОЛДАТСКИХ ЖЕН В ХVII ВЕКЕ}

\author{
Варвара Гелиевна Вовина-Лебедева \\ Санкт-Петербургский институт истории Российской академии наук, \\ г. Санкт-Петербург, Российская Федерация
}

\begin{abstract}
Аннотация. В статье рассматривается одна из важных проблем истории крестьянской семьи XVII в.: отношения к женщине, оставшейся без мужа, со стороны его родни. На неопубликованном материале описания Шенкурской и Подвинской четвертей Важского уезда в 1665 г. проанализированы случаи семейных отношений у крестьян при солдатских наборах, рассмотрены модели дальнейшего взаимодействия волости с семьями солдат. Особое внимание уделяется судьбам солдатских жен. Рассмотрены различные варианты,
\end{abstract}


В.Г. Вовина-Лебедева. «Жена его вышла замуж...»: к вопросу о судьбах солдатских жен в XVII в.

которые зафиксированы в переписной книге: проживание у родственников мужа, у собственных родственников, смерть, «скитание в мире». Одним из таких вариантов являлось замужество солдатской жены. Поскольку случаи, когда оно имело место после смерти первого мужа, всегда фиксировались, остается предположить, что многочисленные записи о случаях иного рода отражают практику особой формы невенчанного сожительства, которую приходится считать довольно широко распространенной.

Ключевые слова: Важский уезд, солдатский набор, переписная книга, солдатская жена, волость, крестьянская семья.

Цитирование. Вовина-Лебедева В. Г. «Жена его вышла замуж...»: к вопросу о судьбах солдатских жен в XVII веке // Вестник Волгоградского государственного университета. Серия 4, История. Регионоведение. Международные отношения. - 2020. - Т. 25, № 1. - C. 44-58. - DOI: https://doi.org/10.15688/jvolsu4.2020.1.4

Введение. Когда речь идет о солдатской службе в XVII в., можно утверждать, что мы многое знаем о том, как формировались выборные полки нового строя, состоящие из служилых людей [6; 7]. Но солдатская служба крестьян, в том числе дворцовых, еще мало изучена. Недостаточно известно, как осуществлялись наборы крестьян в солдаты, например, на Русском Севере, каково было отношение волости к солдатским семьям, что происходило с солдатскими женами. Между тем существуют материалы, позволяющие предложить варианты ответов на эти и некоторые другие вопросы. Так, копии государственных описаний Важского уезда находятся в архиве СПбИИ РАН. В частности, там хранится «тягольно-солдатская» (по определению Ю.С. Васильева [2]) книга Важского уезда 1665 г. [9] (далее - ТСК). Это рукопись из колл. 115, д. 309 (далее при цитировании приводим только листы рукописи в круглых скобках). Она попала сюда из Рукописного отделения БАН, куда, в свою очередь, очевидно, поступила из Архангельска вместе с собранием деловых бумаг Архангельской губернской канцелярии [1]. ТСК в целом никогда не была объектом специального анализа. Нами была ранее исследована часть ее, а именно, описание Кургоминской волости, которой уже были посвящены статьи и публикации $[3 ; 4 ; 5]$. В настоящей статье используется полный текст ТСК и сведения по всем волостям и деревням, в ней упомянутым.

Методы и материалы. Для написания статьи привлечен, таким образом, неопубликованный материал самого раннего из дошедших государственных описаний Важского у., хранящийся в Архиве СПбИИ РАН, ранее не исследованный. Текст данной книги использован полностью, выводы сделаны на основе анализа данных по всем включенным в нее местностям. Было произведено научное описание рукописи, подробно расписано ее содержание и определено, как была построена работа писцов и какие сведения заносились в книгу, материалы по каким волостям в нее включены. При обследовании содержания выявлено несколько вариантов складывания жизни солдатских жен после взятия мужа на службу. Был произведен сплошной подсчет количественных показателей, касающихся положения женщин-солдаток и частотности реализации тех или иных выделенных моделей. Полученные данные подвергнуты анализу исходя из принципа историзма и комплексного исследования данных источника.

Анализ. Книга сохранилась в копии XVIII в., без переплета (переплет изготовлен при реставрации), рукопись F, $22 \times 35$, на 500 л. (по изначальной арабской нумерации чернилами, одновременной с текстом, сохранившимся начиная с л. 9) или 466 л. (согласно карандашной нумерации более позднего времени, далее при цитировании приводим только листы рукописи в круглых скобках). Полуустав разных почерков. Внизу скрепа: «С подлинною переписною книгою читал канцелярист Петр Богатырев». Правые и левые поля отчеркнуты чернилами, пером. На левом поле скрепы: «Секретарь Тимофей Климов, секретарь Петр Соколов». Часть листов утрачена: после л. 184 следует л. 201, л. 226-226 об. пустой. Книга содержит описание 67 крестьянских волостей. Начало отсутствует, текст начинается с середины описания Раченской (Реченской) вол. Далее идут описания следующих волостей (номером л. обозначаем начало описания, используем следующие сокращения: волость - вол., деревня - дер., приход - пр.): л. 14 Великоникольский пр. (Великониколаевская вол.), л. 15 Литвиногорская 
вол., л. 19 Заюмзенская вол., л. 19 об.-20. Рабальская вол., л. 26 об. Тарнянская (Тарненская) вол. Воскресенский пр., л. 32 об. Федорогорская вол., Никольский пр., л. 36 об. вол. Поча, л. 38 Марецкая вол., Преображенский пр., л. 47 об. Вахрушевская вол., Богоявленский пр., л. 49 об. Нижнеедемская вол., л. 52 Шелашская (Шолешская) вол., л. 57 об. Раченская вол. («того ж приходу»), л. 58 вол. Ярупье, л. 60 Усть-Паденская вол., Воскресенский пр., л. 72 Верхопаденская вол., Пречистенский пр., л. 88 Шеренская (Ширенская) вол., Никольский пр., л. 95 об. Ровдинская вол., Борисоглебский пр., л. 104 Суланская вол., Троицкий пр., л. 118 об., Пуйская (Пужская) вол., Георгиевский пр., л. 133 Предтеченский пр., л. 152 Шеговарская вол., Предтеченский пр., л. 155 Сметанинская вол., Предтеченский пр., л. 161 Ямскогорская вол., Покровский пр., л. 177 вол. Золотилова гора, л. 178 Усть-Тарская вол., л. 179 об. вол. Коташка, л. 182 Шеговарская вол., Преображенский пр., л. 209 вол. Верхолецкая слободка, Никольский пр., Усть-Важская вол., Успенский пр., л. 249 вол. Верхняя Тойма, Никольский пр., л. 282 вол. Чащевица, л. 285 речка Уденица, л. 289 об. вол. Другая Верхняя Тойма, л. 305 Нижнетоемская вол., л. 318 вол. Керга, л. 321 об. вол. Заблудня Нижняя, л. 325 вол. Заблудня Верхняя, л. 344 вол. Усть-Емище, л. 347 об. Еминская вол., Нижнетоемский пр., л. 351 об. вол. Качемса, Нижнетоемский пр., л. 353 об. Пучюжская вол., Петровский пр., л. 382 об. Селецкая вол., Ильинский пр., л. 389 Заостровская вол., Архангельский пр., л. 403 Троицкая вол., л. 413 Топеская вол., л. 430 об. Тулгасская вол., пр. Климентовский, л. 436 Кургоминская вол., пр. Воздвиженский, л. 445 Конецгорская вол., пр. Георгиевский, л. 463 об. Ростовская вол., Введенский пр., л. 473 Корбальская вол., Ильинский пр., л. 476 Шиленская и Прилуцкая вол., л. 479 Осиновская вол., Введенский пр., л. 483 об. Слобоцкая вол., Пянская сотня, л. 487 Пяндская вол., Троицкий пр., л. 490 об. Усть-Ваенская вол., л. 493 об. вол. Паница, л. 494 Березницкая вол., л. 496 об. Чаростровская вол.

Это первое из сохранившихся описаний данных местностей. Более ранних переписных книг по Ваге не известно. Степень сохранности книг, подобных ТСК, по другим уездам сейчас нами выясняется. Следует учитывать, что во время составления изучаемого описания шла русско-польская война 1654-1667 гг., поэтому активно велись наборы даточных людей, особенно в дворцовых волостях. В данной книге они называются «солдатами», понятие «даточные люди» не употребляется. В некоторых случаях подчеркнуто, что человек стал «выборным солдатом». Почему именно в 1665 г. возникла необходимость проводить подобную перепись, это вопрос, который еще нуждается в отдельном рассмотрении. Сейчас отметим лишь, что подавляющее большинство крестьян, записанных в ТСК как набранные в солдатскую службу, были взяты в 1654-1655 гг., то есть в самом начале войны, за десять лет до составления книги.

Главный интерес представляет специфика данного описания, которое фиксировало среди других повинностей: подлежал ли двор набору в солдатскую службу, или же нет. В силу этого по какой-то причине писцам было дано задание в случае, если в службу был взят женатый человек, писать о судьбе его жены и детей (имена детей называются, если это мальчики, имена жен не названы). Таким образом, в ТСК отразились некоторые важные черты семейной жизни крестьян гораздо лучше, чем в обычных переписных книгах, где, как известно, отмечались только крестьяне мужского пола (за исключением вдов-дворовладелиц, которые отмечены и в ТСК). Впервые переписывать всех женщин, включая девочек (с обозначением имен и возраста), стали только во время переписи 1710 года. Поэтому анализ ТСК дает ценный материал по истории семьи в России - научного направления, ставшего актуальным благодаря гендерным исследованиям Н.Л. Пушкаревой (из которых сошлемся на последнюю книгу [8]). ТСК также пригодна для сравнения с тем, что известно о положении солдатских жен в XVIII веке [10; 11]. Но в отличие от последующего столетия в исследуемое время положение жен солдат и их детей не регулировалось правовыми актами. В Соборном уложении 1649 г. мельком говорится о службе даточных из частновладельческих крестьян или посадских, а солдаты из дворцовых или черносошных крестьян даже не упоминаются. Отсутствуют другие материалы наподобие 
В.Г. Вовина-Лебедева. «Жена его вышла замуж...»: к вопросу о судьбах солдатских жен в XVII в.

тех, которые позволяют узнать подробности судеб рекрутских жен в более позднее время [11]. В случае Важского у. середины XVII в. мы можем опираться главным образом на данные, извлекаемых из государственных описаний.

Здесь и далее при разборе содержания ТСК будем приводить примеры типичных записей (курсивом нами выделены наиболее важные в каждом случае места). Так, на л. 16 в Раченской вол., дер. Лисицынская описана «вдова Василистка Савина дочь, тягла под ней треть обжи на жеребью, с нею три сына: Наумко десяти лет, Ивашко осми лет да Ивашко ж пяти лет Вахрамеевы дети. Да с того ж тяглово жеребья во 162-м году взят в салдаты пасынок ея Васка Вахрамеев неженатой». Как видим, во время переписи все дворы описывались исходя из двух параметров: размера тягла на жеребей (крестьянский надел) и наличия или отсутствия солдатской службы с двора. Кроме того, отмечались увечья, болезни или старость крестьян. Так, на л. 410 об. в Кургоминской вол., дер. Синцовской был описан «Овдейко Емельянов стар и крив. Тягла под ним пол полтрети и малая четь обжи на жеребью. С ним сын Ивашко женатой, салдаикие службы с него нет».

Долгота службы была различной, но она не всегда отмечалась писцами. Зачастую делалась лишь помета о том, что человек «в службе был» (означавшая, что он к 1665 г. со службы уже вернулся). В противном случае записывалось, что крестьянин «сшел за себя», то есть не нанял «наемщика», что тоже было возможно и довольно широко практиковалось. Заметка «сшел за себя» означала, что человек пошел служить сам и все еще служит. Но иногда делалась специальная приписка «и ныне в службе» или писалось, сколько лет было отслужено.

Например, на л. 406 в Кургоминской вол. в дер. Анкудиновской описан «Назарко Григорьев. Тягла под ним полчети обжи на жеребью. С ним сын Левка женат. И во 163-м году он, Левка, описан в салдаты и в службе бывал. А отец ево стар и дряхл». Как видим, если женатый крестьянин к моменту описания уже возвратился со службы, судьба его жены не указывалась, и мы лишены возможности понять, где она обитала во время его отсутствия. Обычно не ясно даже, сколько лет его не было дома. Так, на л. 411. Кургоминская вол., дер. Синцовская читаем: «Андрюшка Самойлов. Тягла под ним полтрети и пол полчети обжи. И во 163-м году он, Андрюшка, описан в салдаты от отца $и$ в службе был год, a ныне одинок и отец ево умре». Фразу «а ныне одинок» можно трактовать двояко: и как то, что Андрюшка лишился отца, и как то, что Андрюшка был женат, а теперь нет.

Длительность службы была различной. На л. 406 об. в Кургоминской вол., в описании дер. Гавриловской читаем: «Ивашко Семенов. Тягла под ним пол полтрети и пол малые трети обжи. Одинок. И во 163-м году он, Ивашко, описан в салдаты от брата от Оферка и в ево место был на государеве службе брат ево родной он, Оферко, два годы и пришед домой». Крестьянин мог отсутствовать и гораздо дольше: на л. 227. В Усть-Важской вол. описана дер. Котоцкая. Там двором владел Петрушко Деонисьев «стар». Его сын Тимошка в 7162-м г. был описан в солдаты «и в службе был 8 лет». В большинстве же случаев, когда речь шла о взятых в службу в 1654 или 1655 гг. лицах без всякой иной пометы, это означало, что крестьяне до сих пор (то есть к моменту описания) находились в службе, то есть служили 10 лет и долее.

В обязательном порядке указывалось семейное состояние крестьян, как живущих во дворе, так и взятых с этого двора в солдаты. Если дворовладелец был неженат, это отмечалось понятием «одинок», поэтому отсутствие такой пометы означало, что владелец двора женат. Если двором владела женщина, она обозначалась как «вдова». Так, на л. 404 в Кургоминской вол., в дер. Ефремовской значился «Ивашко Иванов, тягла под ним пол трети обжи и пол полчети и шестая доля белки, одинок. Да от него ж Ивашка, во 163-м году с того же тяглово жеребья взят в салдаты брат ево родной Федка, неженатой, сшел за себя. А тяглово салдацкого жеребья Ивашко в мир не поступаетца, пашет и подати платит собою». На л. 213 об. описана Усть-Важская вол., дер. Балавинская. Там проживал Оска Якимов «слеп», в 7163-м году в солдаты был взят его сын Мелешка «женатой, был в службе, а ныне дома». Семейное состояние взятого на службу обозначалось всегда. 
См. л. 402 об. Кургоменская вол., дер. Калининская: «И во 163-м году муж ея, Маринкин, Ермолка Титов описан в салдаты, и в ево место сшел на государеву службу в салдаты брат ево родной Игнашка, неженатой. А Ермолка дома умре». Перед нами часто встречающееся явление: вместо одного члена семьи на службу шел другой (обычно брат, сын или отец).

Перейдем теперь непосредственно к судьбам жен-солдаток. Судя по ТСК, существовало ограниченное число возможностей для женщины устроить свою жизнь, если мужа забирали в солдатскую службу. Гибель мужа на службе никак не влияла на судьбу его жены и не влекла за собой никакой компенсации. Тем не менее смерть в службе всегда отмечалась, и мы можем понять, что такие случаи не были единичными. Если речь шла о гибели во время боевых действий, это записывалось особо. Так, солдаты гибли под Смоленском. Пример типичной записи: в Конецгорской вол., в дер. Тереховской (л. 451) описан взятый в 7162-м году в солдаты подворник Михейко Савин, который «сшел за себя и под Смоленским убит». Как увидим далее, уход крестьянина (в случае, если он был женат) на 10 лет и более в солдаты без гарантии того, что он вообще возвратится, ставил его жену и детей на грань выживания. Поскольку никакой государственной поддержки семьям солдат не существовало, солдаткам приходилось рассчитывать на родственников или на помощь волости (мира).

Нами были выделены различные варианты судеб солдаток и проведены подсчеты частотности проявления того или иного варианта в пределах волостей, охваченных описанием ТСК. О судьбе жены солдата ничего не сказано лишь в пяти случаях (см. л. 72 об., л. 90, л. 249 об., л. 251 об., л. 404 об.) При этом тут могли иметь место просто ошибки при прочтении и последующем копировании, в результате которых вместо «неженатый» переписчик мог прочесть (и машинально написать) «женатый». Приведем пример: на л. 72 об. при описании Верхопаденской вол. в дер. Галиева Гора обозначен Тимошка Васильев, у которого в 7162 г. взят в солдаты брат его «женатый» с простой пометой, что он «сшел за себя». Поскольку обычно при описи в солдаты женатого крестьянина говорилось о судь- бе жены и детей, то данное место мы должны считать ошибкой, и брат Тимошки Васильева, видимо, был «неженатый».

Теперь отметим крайне редкие случаи, когда солдатские жены после ухода мужа в службу отделялись от его родных и жили своим двором. В ТСК мы обнаружили это четыре раза (см. л. 29, л. 96 об., л. 139, л. 293 об.). На л. 29 читаем, что в Рабальской вол., в дер. Ивановской в 7162 г. со двора Стенки Иванова был взят в солдатскую службу его брат Никитка. После этого Никиткина жена Ксеньица «да дети Першка женатой, Игнашка тринатцати лет во 170-м году от Стенки omделились и живут собно своим двором». Причиной такой самостоятельности Ксеньицы, видимо, нужно считать наличие у нее взрослого сына. Вероятно, именно женитьба сына сделала возможным отделение спустя 8 лет после ухода мужа в солдаты. На л. 96 об. в Ровдинской вол., в дер. Стрыковской находим Петрушку Михеева, у которого вместо сына Давыдка пошел в солдаты его брат Матюшко, после чего «жена ево Матюшкина Овдотьица Архипова дочь от него Петрушки отделилась и живет своим двором». Тут причина отделения солдатки явно иная, так как, судя по описанию, у нее вообще не было детей (во всяком случае, сыновей). Скорее всего, отделение Овдотьицы было своего рода компенсацией за то, что ее муж пошел в службу вместо брата. На л. 139 в Предтеченском пр., в дер. Кобылинской дворовладелицей значилась Маврица Трофимова. Ее муж Дружинко Иванов в 7163 был взят в солдаты от братьев Анашки и Онички Ивановых, «и после ево Дружинки, жена ево и дети от Анашки отделились». Возраст детей, как видим, не указан, скорее всего, они были малолетними и, вероятно, это были девочки, поскольку они не названы по имени. Фразу «после ево Дружинки» можно понимать и как указание на уход в службу, и как указание на смерть Дружинки. Наконец, в вол. Другая Верхняя Тойма, в дер. Голубовская (см. л. 293 об.) жил Панкратко Никифоров, у которого в 7162 со двора в солдаты был взят брат Пашко, а жена и 12-летний сын последнего «живут своим двором, отделясь».

Итак, во всех четырех случаях перед нами разная ситуация семейного раздела: от- 
В.Г. Вовина-Лебедева. «Жена его вышла замуж...»: к вопросу о судьбах солдатских жен в XVII в.

деляется жена со взрослым сыном; бездетная солдатка; крестьянка с малолетними (возраст не определен) детьми; жена-солдатка и сын-подросток.

Следующим вариантом женской судьбы, который выявляется при анализе ТСК, была смерть жены солдата, пока муж был в службе. Жены умерли в 47 случаях. Записи об этом предельно лаконичны. Так, в Предтеченском пр., в дер. Кулагинская (л. 142) у Гришки Кузмина был взят в солдаты женатый сын Ивашка, и далее сказано, что его «жена умре». И в той же дер. у Якунки Алексеева в 7162 г. забрали женатого брата Стенку, а его «юена умре».

Солдатский жеребей был продан женою после ухода мужа в службу в пяти случаях (л. 17, л. 28 об., л. 33-33 об., л. 89 об., л. 171 об.). Так, в Литвиногорской вол., в описании дер. Оладинская (л. 17) читаем: «Тое ж деревни с тяглово жеребья сшел на государеву службу в наемных салдатех Коземко Пахомов вместо описного салдата Усть-Тарненские ж волости Архипка Игнатьева сына Лодыгина ж. Тягла под ним Коземкою было пол обжи, и после Коземки жена ево Федосьииа тот тяглой жеребей для своей бедности продала Федке Яковлеву да сын ея Федосьицын Данко Козмин во 170 году нанялся в салдаты вместо описного салдата Сенки Харламова с Перевозу и ныне в службе». В данном случае взятый в службу крестьянин был дворовладельцем, но в службу пошел добровольно, очевидно, в силу бедности, продавшись как «наемный солдат» вместо крестьянина, который должен был пойти в солдаты («описной солдат») из другой волости. Это не помогло семье, и жена Коземки все же продала оставшийся после мужа жеребей, также в силу бедности. Этого оказалось недостаточно, и через 8 лет ее сын вынужден был наняться в солдаты, как и отец, пойдя в службу за другого. Он служил к моменту переписи уже три года (с 1662 по 1665 г.). Воображение рисует эту незадачливую семью. Можно лишь гадать, в чем была причина такого несчастья. Для писцов важной задачей было показать, куда ушел надел и кто им теперь владеет, что и было тщательно зафиксировано. На л. 28 об. в дер. Фоминской, Куликова и Сараевская тоже находим Ивашку Силуянова «стара», у которого в солдаты был взят женатый сын Захарко. Но за него пошел наемщик Терешко Арефьев «и ныне в службе, а жена ево, Терешкина, после ево той жеребей в 166-м году продала и скитаетца ныне в мире». Отсюда следует, что писцов интересовала судьба всех жен-солдаток, включая и жен «наемщиков». То, что результатом продажи надела для солдатки чаще всего было «скитание в мире», в целом очевидно. О «скитающихся в мире» солдатках см. ниже.

Только в некоторых случаях мы можем узнать, где затем обитали продавшие надел женщины. Так, в Ширенской вол., в дер. Трофимовской (см. л. 89 об.) жил Анфилофейко Филипов, у которого в службу был взят женатый брат Ивашко, после чего «жена ево Ивашкова да сын Первушка десяти лет от нево Анфилофейка отделились и тяглой салдаикой жеребей продали ему ж Анфилофейку и живут в Усть-Паденской волости на подворье у дядьев своих». Тут на помощь солдатке с сыном пришли ее родственники (не родственники мужа). Что же касается брата мужа, то он получил выгоду из этой ситуации, прикупив жеребей брата. Еще один вариант описан на л. 33-33 об. В вол. Федорогорской Никольского пр. зафиксирован Ивашко Матвеев, который в 7163 г. был описан в солдаты от отца, но вместо него в службу пошел наемщик, крестьянин той же волости, дер. Жемчужинские, Сенка Иванов, который «и ныне в службе» (то есть уже 10 лет), а тем временем «наемщиков тяглой жеребей жена ево продала и вышла замуж». К случаям выхода замуж солдатских жен мы вернемся ниже. Остается лишь гадать, куда ушли деньги, вырученные за продажу мужнина надела. Если они ушли в семью второго мужа, то любопытно было бы узнать, какова была тут позиция родственников первого. Наконец, писцы могли просто зафиксировать факт продажи надела, не выясняя судьбу продавшей его жены (или, возможно, им это не удавалось выяснить). В Предтеченском пр., в дер. Летушинской (см. л. 171 об.) у Левки Тимофеева «стара» в 7162 г. в солдаты были взяты сыновья Васка и Ивашка. Вместо Васки пошел наемщик Усть-Тарненские волости Патрикейко Агафонов Коробицын, оставив жену, о которой просто сказано, что «тяглой ево жеребей жена ево продала». 
Наделы, однако, могли продавать не только жены. В той же волости в дер. с говорящим названием Ивановская и Мудаковская (см. л. 24) жил неженатый Васка Яковлев, который был описан в солдаты, «сшел за себя, был записан от отца и отец без него умре, а тяглой ево жеребей... без него Васки сестра ево продала тое ж деревни вдове Улите Савостьянове дочери». Итак, тут перед нами следы операции купли-продажи земли, которую в отсутствие мужчин (один ушел в солдаты, другой умер) осуществили женщины.

Редко жена солдата становилась владелицей тяглого жеребья. Иногда перед этим она отделялась от родственников. В ТСК мы встречаем эту ситуацию только трижды. Любопытно, что везде речь идет о «наемщиках», пошедших в службу вместо описанного в солдаты крестьянина. Так, у крестьянина Ровдинской вол., дер. Сидорова Горка (см. л. 105) Сенки Анисимова был описан в службу сын, вместо которого пошел наемщик из той же волости из дер. Ильинской Андрюшка Гаврилов, после чего «тяглым ево наемщиковым жеребьем владеет жена ево». В Пуйской вол. в дер. Палинская (л. 119 об.) за крестьянина Федотку Тиханова пошел в службу наемщик, а «тяглым ево наемщиковым жеребьем владеет жена ево да дети». И в той же деревне отмечен случай ухода в солдаты наемщика Тимошки Яковлева, о котором сказано (л. 121 об.), что на жеребье у него остались жена и дети. Итак, у нас три случая владения солдатками тяглым жеребьем: одинокой женщиной (или не имеющей сыновей) и матерями вместе с детьми, возраст которых не обозначен.

И однажды писцами было помечено, что жена солдата Тимошки Васильева, который был описан в службу от своего брата Мартинки Васильева из дер. Никольской Ровдинской вол. (л. 114), живет вместе с сыном «в Шенкурске на посаде». При этом нет никаких помет о том, что в Шенкурске у них имелась родня. Очевидно, были какие-то другие причины, заставившие жену Тимошки Васильева покинуть родную деревню и устроиться жить в городе. При наличии родственников, прежде всего со стороны мужа, женам и детям естественно было ожидать помощи с их стороны, особенно в случае, когда муж описывался в солдаты со двора от отца или старшего брата.

У родни мужа жило всего 115 солдаток. Из них наиболее часто они принимались (с детьми или без) деверем (братом мужа): 64 случая. Так, в дер. Фалковской Заюмзенской вол. (л. 19 об.) жил Ивашко Наумов, у которого «во 162-м году с того же тяглово жеребья взят в салдаты брат ево родной Васка женатой и ...в службу сшел за себя», после чего Васкина жена жила у Ивашки. Ее семейный статус (наличие или отсутствие детей) не был отмечен. На л. 63. в Усть-Паденской вол., в дер. Лукинской описан Якушко Тарасов, у которого в солдаты был взят брат, после чего бездетная (что специально отмечено) жена его живет у Якушки. А в Шелашской вол., в дер. Лукинской (л. 63) жил Якушко Тарасов, у которого в службе находился брат, а его «жена бездетна живет у Якушки». Видимо, помета «бездетна» означает, что у солдатки в самом деле не было детей, а если по этому поводу не делалось никакой пометы, это могло значить лишь, что отсутствуют дети мужского пола, но могли быть дочери, которые просто не записывались в ТСК.

В некоторых случаях хозяин двора содержал большую семью родственников по линии своих братьев: не только жену ушедшего в солдаты брата, но и племянников. Так, на л. 408 об. в Кургоминской вол., в дер. под названием Что был починок Сеньки Григорьева, отмечен Агафонко Филипов. С ним во дворе описаны два племянника: «Сидорко Савин десяти лет, Ивашко Федоров осми лет». С этого же жеребья были взяты в солдаты три родных брата Агафонка: «Савка да Федорко женатые, Лучка неженатой». Федка был взят в 7162 г., а Савка и Лучка - в 7163 году. Все трое «сошли за себя». Из двух солдатских жен Савкина жена вышла замуж, а Федкина жена продолжала жить во дворе Агафонки, как и ее сын. Любопытно, что и сын Савки 10 лет продолжал жить у дяди, несмотря на то что его мать уже ушла со двора. И это случай не единичный, встречаются и другие. Так, в дер. Седельниковская и Старухинская Рабальской вол. (л. 23-23 об.) во дворе Никифорки Максимова жил «с ним брат родной Андрюшка дватцати лет, да от него ж Никифорка... с того ж тяглово жеребья взят в 
В.Г. Вовина-Лебедева. «Жена его вышла замуж...»: к вопросу о судьбах солдатских жен в XVII в.

салдаты брат ево родной Федка женатой, сшел за себя, жена ево вышла замуж, а дети его, Федкины, Ивашко десяти лет и Коземко осми лет живут у него ж, Никифорка...». Как видим, сыновья ушедшего в службу брата хозяина двора всегда описывались с указанием возраста. Так и в вол. Ширенской, дер. Онтипинской (л. 88 об.) двором владел Васка Артемьев, описан в службу от него был брат Семейка, жена которого и сын Ферапонтко 10 лет жили у Васки.

Вторым по частотности упоминания в ТСК был вариант, когда солдатская жена оставалась жить у свекра: 37 случаев. Так, на л. 404 об. в Кургоменской вол., в дер. Прокопьевской отмечен «Епифанко Иванов. Тягла под ним четь и полчети обжи на жеребью. С ним внук Осташко Иванов десяти лет. Да от него, Епифанка, во 163-м году с того тяглого жеребья взят в салдаты сын ево Ивашко женатой, сшел за себя. Жена ево живет у него, Епифанка». Из записи не явствует прямо, что жена Ивашки и есть мать внука Осташки, но это резонно предположить. Иногда на одном дворе жили жены нескольких солдат. Так, на л. 135 в Предтеченском пр. в дер. Гришинской и Манастырек жил Гашко Шатров, у которого сначала в солдаты был взят сын Ивашко, «а ныне в выборных солдатех, жена ево живет у него Гашка», затем в солдаты взяли зятя Ивашко, жена которого также жила после этого у Гашки.

Четыре раза встречаются записи о том, что солдатские жены оставались жить у вдовой свекрови. Так, в Рабальской вол. в дер. Харловской (л. 77 об.) жила вдова Иринка Осипова, женатый сын которой был взят в солдаты, после чего его жена жила с Иринкой. Она не записана бездетной, но и не обозначены сыновья. Значит, после ухода в службу единственного мужчины в семье во дворе остались жить женщины: вдовая Иринка Осипова, ее невестка и дочери последней. Такой же случай видим в Ровдинской вол.: на л. 111 об. в дер. Захаровская и Шевелевская записана вдова Фотиньица Анисимова, у которой в службу взят сын, а жена сына живет у Фотиньицы. А на л. 154 в Шеговарской вол., в дер. Игнатьевской означена вдова Матица Софонова. В 7162 г. в солдаты были взяты два ее сына: «Левка да Тимошка». Судьбы их жен сложились по-разному: про Левку сказано, что он «ныне в службе в выборных солдатех», и Левкина жена живет у Матицы. А вот Тимошкина жена вышла замуж. Наконец, в Сметанинской вол. (л. 155 об.) в дер. Тихоновской у вдовы Дарьицы Синичихи был в 7163 г. взят в службу сын Ивашко, «и был в службе, а ныне слеп, жывет на Москве, просит хлеба, жена ево жывет у нее, Дарьицы». Таким образом, жена и, видимо, дочери пострадавшего на службе и (видимо, поэтому) не вернувшегося в деревню сына продолжали опекаться его матерью (и, разумеется, работать) на ее дворе.

Нередко во дворах своих родственников по линии мужа оставались жить жены зятьев, дядей или племянников хозяина двора: 10 случаев. Так, например, в Сметанинской вол. в дер. Зеленинской (л. 173) жил Семейка Агафонов, у которого в службу в 7163 г. был взят племянник Исачко Герасимов, и теперь «жена ево живет с ним Семейкой и печалует». В Пучюжской вол. в дер. Яковлевской (л. 371) описан Стенка Якимов, у которого в 7162-м г. был взят племянник Ивашко Никифоров, и жена последнего теперь живет у Стенки. На л. 31 в Рабальской вол. в дер. Рыбина Горка находим Сидорку Куприянова, у которого был взят в службу зять, и жена последнего с тех пор живет у Сидорки. В Ровдинской вол., в дер. Стрыковская (л. 97 об.) читаем об Ивашке Васильеве, сын которого Кирилка подлежал взятию в солдаты, но вместо него пошел его дядя Никифорко Васильев, жена которого теперь живет у Ивашки. В Нижнетоемской вол. в дер., которая в описании названа Что, была пустошь Другое Фоминское (л. 313), со двора Исачки Савинова в 7162 г. был взят его дядя, жена которого теперь живет у Исачки. А на л. 314-314 об. читаем про Терешку Федорова, у которого в 7163 г. также был взят дядя, и жена дяди живет у Терешки.

Впрочем, отношения между дядьями и племянниками могли быть довольно сложными. Так, на л. 12 об. в Раченской вол. в дер. Киприяновской значится Агапко Минин, вместе с которым жил «племянник Ивашко Сергиев женатой». История семьи заключалась в том, что в 7163 г. «два племянника ево два Ивашка Сергиевы дети женатые отписаны в салдаты» и «болшеи Ивашко в службу сшел 
за себя, а вместо другова Ивашка сшел дядя ево Гришка Минин женатой». Таким образом, сейчас во дворе Агапки остался лишь один, младший племянник хозяина, а также жена другого племянника, ушедшего в службу. Но жена Гришки Минина, который пошел служить за младшего племянника, «скитаетия в мире», и Агапко по какой-то причине не взял на себя заботу о ней.

Мы рассмотрели примеры дворов, хозяева которых собирали вокруг себя многочисленную родню, в том числе оставшихся без кормильца жен и детей солдат, взятых в службу с этого двора. Однако это происходило далеко не всегда. Отметим сначала записи, согласно которым солдатские жены жили не у родни мужа, а у своей родни. У своих братьев они проживали в двух случаях. На л. 161 читаем, что в Ямтогорской вол., в Покровском пр., в дер. Соболевской жил Давыдко Ерофеев Губин. В 7163 г. был взят в солдаты его брат Мишка, жена которого теперь «жывет у братьи своей родных». В Троицкой вол. в дер. Тимохинской (л. 410) записан крестьянин по имени «Федка Иванов Синцов, тягла под ним треть обжи на жеребью, с ним сын Пашка женатой да от него ж Федки во 7163-м году взяты в салдаты два сына ево Флорко женатой, Стенка неженатой, сошли за себя. Флоркова жена живет у братьи своей родных...». Третий похожий случай был указан выше, когда речь шла о продаже женами солдатских жеребьев: в вол. Ширенской (л. 89 об.) солдатская жена продала солдатский жеребей брату своего мужа, после чего жила в другой волости «на подворье у дядьев своих».

У своего отца после ухода мужа в службу солдатские жены проживали в двух случаях. Так, в Литвиногорской вол. в дер. Пасыновской (л. 73) жил Федотко Заморов, у которого был взят в солдаты его женатый сын, а теперь «жена ево бездетна живет у отца своево». А в Пучюжской вол. в дер. Лухановской (л. 360) у Васки Яковлева в 7163 г. взяли брата Ивашку, и его жена также живет у своего отца.

У собственных матерей солдатские жены жили также только в двух случаях. На л. 360 об. значится Костка Яковлев, у которого в 7163 г. был взят в службу брат Аничка, жена которого после этого жила «у матери своей». И аналогично этому в дер. Евдокимовской Пучюжской вол. (л. 380) у Харки Андреева был взят в 7163 г. сын Якушко, а его жена «живет у матери своей».

Всего по материалам нашей переписной книги жила у родственников (мужниных и своих) 121 солдатка.

Трижды мы видим записи о том, что женщины не жили у родни (ни у мужниной, ни у своей), но кормились с помощью родни. Так, в Усть-Важской вол., Успенском пр., в дер. Моисеевской (л. 233) значится Маковейко Дмитриев. Его сын Амброско в 7162 г. да брат Ивашко в 7163 г. были взяты в службу, после чего "Амброскова жена вышла замуж, а Ивашкове жене он, Маковейко, дает nocыnной хлеб». В Нижнетоемской вол. в дер. Третья Борисовская (л. 306) записан Чюдинко Иванов, у которого в 7162 г. взят брат Мишка женатый, и «жене ево Мишкине он Чюдинко дает посыпной хлеб». Наконец, на л. 306 об. находим Терешку Клементьева «одинока». В 7162 г. у него был взят в службу брат родной Фомка, и жене последнего Терешка дaem посыпной хлеб.

Итак, с учетом этих трех случаев, 124 солдатские жены получили помощь от родни после ухода мужа в службу.

Иногда во дворах оставались жить жены наемщиков, пошедших в службу вместо кого-то из жильцов данного двора. Приведем пример. В Ровдинской вол. в дер. Кабаловская Горка (л. 106) жил Федка Никитин, у которого был описан в службу сначала один сын, который пошел за себя, его жена и сын живут у Федки. Затем описали и другого сына Дмитренка, вместо которого выставили «наемщика», и жена этого наемщика теперь «живет у Минки», то есть у того, вместо кого пошел в службу ее муж. Думается, что в подобной ситуации можно предполагать предварительный уговор наемщика и того, кто его нанимал в службу, относительно судьбы наемщиковой жены.

Однако гораздо чаще жена солдата оказывалась вообще без всякой помощи родственников и была вынуждена нищенствовать, надеясь на помощь волости - идти по миру, или, как значится в ТСК, «скитаться в мире». Всего, по нашим подсчетам по ТСК, в 1665 г. скитались в мире 79 солдатских жен. При этом 
В.Г. Вовина-Лебедева. «Жена его вышла замуж...»: к вопросу о судьбах солдатских жен в XVII в.

иногда отмечается, что жены скитаются «бездетны». Мы насчитали 11 таких случаев. Так, в Ровдинской вол. в дер. Чикаловской (л. 102) у Половки Никифорова в 7162 г. был взят в службу родной брат, и теперь его «жена бездетна скитается в мире». Также и на л. 102 об. в той же вол. в дер. Уласовской у Матюшки Анаибина взяли брата Ивашку, жена которого «бездетна скитается в мире». Иногда в одной семье это становилось правилом. Так, в Рабальской вол. в дер. Можаевская и Тупиковская (л. 25) в службу были взяты Лучка Тимофеев и Андрюшка Александров женатые, «жены их скитаютща в мире, бездетныр».

Если у солдатской жены были сыновья, которые также пошли по миру, это всегда отмечалось: мы насчитали 10 случаев. Так, в Заостровской вол. в дер. Михайловской (л. 392) у Агафонки Якимова в 7163 г. был взят в службу брат Софонко, жена и 9-летний сын которого теперь скитаются в мире. А в Раченской вол. в дер. Жерноковской (л. 14 об.) записан Ивашко Томилов сын Рачков, у которого «брат ево родной Ивашко же женатой сшел за себя, а жена ево Ивашкова да два сына Фирко пятинатцати лет и Шилко десяти лет скитаютца в мире». Попадаются сведения о еще более многочисленных группах родственников, обреченных на нищенство. Так, в дер. Водокушка Предтеченского пр. (л. 141) Харка Агафонов из Ямскогорской вол. был описан в солдаты в 7163 г., но в его место в службу пошел брат. Харко продал жеребей в Ямскогорской вол. и купил землю на Водокушке у старцев Кодемской пустыни, «что положил к ним вкладом тое ж деревни Олферко Слобожанин, а с того жеребья ево Олферковы три сына Матюшка женатой, Игнашка да Оска неженатые взяты в солдаты во 163-м году, сошли за себя, а отец их умре», после чего «Матюшкина мати и жена $и$ сын Савка девяти лет да брат родной Якушко пятинатцати лет скитаютца в мире».

Есть случаи более сложные. На л. 404 об. в Троицкой вол. в дер. Сергиевской находим двор, которым владел «Ивашка Корнилов сын Спицын одинок. Тягла под ним пол обжи без полполчети обжи, да ево ж подворник Тришко Михайлов сын Бушарин взят в салдаты во 7163-м году, сшел за себя, жена ево Тришко- ва да сын Васка девяти лет скитаютца в мире, а живут на подворье у него ж Ивашка». Таким образом, одинокий крестьянин предоставил кров жене и сыну своего подворника, но, видимо, этим и ограничился, и их не кормил, поскольку они считались «скитающимися в мире».

Чаще всего жены обозначены «скитающимися в мире» без обозначения бездетности, но и без записи сыновей. Таких случаев 57. Можно предположить (как уже было отмечено выше), что эти неустроенные солдатские жены имели не сыновей, а дочерей. Так, в Рабальской вол. в дер. Парчинской (л. 25) значился жеребий Федки Кузмина Узлового, «что лежит в пусте». Сначала с него были взяты в солдаты брат Федки Митрошко и сын Ивашка, оба женатые, оба «сошли за себя и ныне в службе». Потом и сам Федка «сшел на государеву ж службу вместо описного салдата Химаневские волости деревни Коскары (?) Мишки Агафонова прозвищем Докучки по найму, и ныне в службе, жены их скитаютца в мире». Тут перед нами кратко записана история разрушенной солдатскими наборами семьи. Не удивительно также, что «скиталась в мире» после ухода в солдаты жена «беспашенного бобыля Мирошки» из дер. Шитиновской Рабальской вол. (л. 26).

Но в большинстве случаев жены солдат пускались по миру при живых и находившихся в своих дворах родственниках. Так, приведем пример характерной записи на л. 42 об.: в Марецкой вол. в дер. Утятинской жил Стенка Михайлов, брат которого Симка был взят в службу, а жена его скитается в мире. Причины такого поведения родственников по отношению к солдатским женам определить трудно. В ряде случаев это, возможно, объяснялось перенаселенностью дворов. Но иногда подобная ситуация складывалась даже во дворах, владельцы которых значатся как «одинокие». Так, в Литвиногорской вол. в дер. Якимовской (л. 18 об.) записан «Гришка Андреев... да во 7163-м году описан в салдаты брат ево родной Митка женатой, и Митка в службу сшел за себя, жена ево скитаетца в мире, а Гришка ныне одинок». Чаще всего солдатская жена скиталась в мире, когда ее муж был взят со двора своего брата, которому достался «солдатский жеребей», но который не стал 
содержать невестку. Однако не менее равнодушными к судьбе снохи оказывались порой в таких случаях и свекры. Так, в Шеговарской вол. в дер. Игнатьевской (л. 152 об.) записан Анкидинко Борисов, сын которого по имени Девятко взят в службу, а жена его «скитается в мире».

Теперь мы переходим к самому неожиданному варианту судеб солдатских жен. Речь идет о случаях, когда солдатские жены вновь выходили замуж. Это наиболее часто встречающийся вариант их устройства. Но сложность заключается в том, что лишь в немногих случаях в ТСК указано, что муж солдатки, вышедшей замуж, умер. Таких случаев мы насчитали 21.

Приведем типичные примеры подобных записей. В вол. Верхняя Тойма в дер. Киверевской (л. 250 об.) со двора Сенки Калинина в 7162 г. был взят брат, который «сшел за себя и под Смоленским убит, а жена ево вышла замуж». В Корбальской вол., пр. Ильинский, в дер. Остолоповской (л. 473) у вдовы Ириньицы Стахиевой был взят в 7162 г. деверь Левка Тимофеев «и под Быховым убит, жена вышла замуж». В той же вол., в дер. Ивановской на церковном дворе (л. 474 об.) записан третник Сенка Алимпиев, сын которого Лаврушка был взят в службу в 7162 г. «u в службе умре, жена вышла замуж». В Кургоминской вол., в дер. Селивановской, у «жилца Терешки Карпова взяты в салдаты два сына: Андрюшка да Кирюшка женатые. И в службе умерли. Андрюшкина жена скитаетца в мире, а Кирюшкина жена вышла замуж. А записаны были от отца и отец их умре. А тяглым их жеребьем владеет Ивашко Семенов по купчей» (л. 406 об.-407). Та солдатка, которая вышла замуж, видимо, считалась пристроенной, та, которой это не удалось, «скитаетца в мире».

Строго говоря, из приведенных записей непонятно, произошло вторичное замужество уже после смерти первого мужа или же нет. Здравый смысл толкает к первому варианту интерпретации, и тут не возникло бы даже сомнений, если бы не было выявлено неожиданно большое количество записей о замужестве солдатских жен, в которых о смерти первого мужа ничего не сказано: 140 случаев.
Например, в Кургоминской вол., в дер. Селивановской жил «Васка Семенов... С ним сын Ивашко осми лет. Да ево ж подворник племянник Сенка Евтихеев женатой взят в салдаты во 162-м году, сшел за себя. А у Васки взял подмог. Жена ево Сенкина вышла замуж» (л. 405). Обращает на себя внимание деталь: племянник живет в подворниках у дяди, именно поэтому, видимо, тот и дал ему по-родственному «подмог». Другой случай в той же деревне: «Гаврилко Васильев... И во 163-м году он, Гаврилко, описан в салдаты от отца. И в ево место сшел на государеву службу наемщик ево Заостровские волости Лучка Клементьев Корноухов. А от отца он, Гашко, отделился тому шесть годов. Да с того ж тяглово жеребья во 163-м году взят в салдаты брат ево родной Нестерко Ермолин женатой, сшел за себя, жена ево вышла замуж» (л. 405).

Поскольку мы знаем, что смерть солдат в службе тщательно фиксировалась писцами, нельзя отвергать единственное оставшееся объяснение: оставшиеся без мужа солдатские жены, видимо, в основном те, которые не могли найти поддержку у своей родни или родни мужа, снова выходили замуж, не дожидаясь возвращения мужа из службы. Если это так, то речь, разумеется, должна идти о невенчанном браке, признающемся, однако, общиной, поскольку о нем сообщалось писцам.

Поскольку данное предположение кажется на первый взгляд слишком смелым, мы постарались найти места, относительно которых можно с уверенностью утверждать, что тут на момент второго замужества своей жены, ее первый муж-солдат был еще жив. Таких фрагментов оказалось три.

На л. 14 в Великоникольском пр. в дер. Чюпраковской находим большую запись о семье крестьянина Илюшки Самсонова. Кроме него во дворе были записаны «ево ж Илюшкины два сына Васка да Мишка на Москве в стрелцах», а также Федка Артемьев Поромов. Они владели тяглым жеребьем прежнего жильца «Мишки Артемьева прозвищем Семого», у которого в 7163-м г. были взяты в солдаты два сына его «Васка да Гришка женатые, да Гришкин сын Ивашко неженатой. И Васка и Ивашко в службе сошли за себя, а Гришка в службе был же и пришед из служ- 
В.Г. Вовина-Лебедева. «Жена его вышла замуж...»: к вопросу о судьбах солдатских жен в XVII в.

бы, дома умре». Пока необычного в данной записи было лишь то, что там не сказано о судьбе Васкиной жены (о Гришкиной жене не говорится потому, что он уже вернулся со службы). Но далее идет ценная для нас фраза: «Да ево ж Мишкин брат родной Васка женатой сшел в наемные салдаты вместо описного салдата Вахрушевские волости Коземки Поромова $и$ ныне в службе, а Мишка после тех салдат умре, а жены их салдацкие вылили замуж». Итак, мы находим сообщение о судьбе Васкиной жены: она вышла замуж. Но приходится признать, что вышла замуж также и жена Коземки Поромова, иначе «жены» не употреблялись бы во множественном числе. А ведь Коземка Поромов находился на службе в 1665 г., о чем сообщается недвусмысленно: «и ныне в службе», значит, он был жив. Не менее определенное указание на вторичное замужество солдатской жены при живом первом муже мы получаем при анализе ситуации, описанной на л. 3333 об. (на которую мы уже указывали выше, когда речь шла о продаже женами солдатских жеребьев). В Федорогорской вол. Никольского пр. Ивашко Матвеев в 7163 г. был описан от отца в солдаты. Вместо него пошел наемщик, той же волости дер. Жемчужинские Сенка Иванов, о котором сказано, что он «и ныне в службе», «а наемщиков тяглой жеребей жена ево продала и вышла замуж». И, наконец, в вол. Верхняя Тойма (л. 249 об.-250) указан взятый в солдатскую службу «бобыль Порошка Карпов женатой, жена ево вышла замуж, а он сшел за себя, и ныне в службе».

Обнаружение данных записей наводит на мысль, что и во всех других 140 случаях (которые мы выше уже заподозрили в том, что это записи о невенчанных браках жен-солдаток) наши подозрения имеют под собой почву. Собственно говоря, наиболее шокирующим обстоятельством тут является (с современной точки зрения) не сам факт сожительства жен-солдаток во время службы мужей, а то, что это было занесено в переписную книгу, то есть, по сути, признано государственной властью. Можно думать, что солдатки выходили замуж за местных крестьян. Поскольку нами были обнаружены в 1665 г. многочисленные одинокие крестьяне-дворовладельцы, осторожно предположим, что молодых женщин, возможно, в некоторых волостях не хватало, в особенности бездетных. Вспомним, что среди «скитающихся в мире» солдатских жен бездетных нами обнаружено всего 11.

В двух случаях, как можно предположить, мы видим ситуацию с другой стороны: со стороны того, кто женился на солдатской жене. Оба раза новые мужья оказались пришлыми во двор своей жены. В Тарненской вол., в дер. Ильинской (л. 27) описан «Бориска Никифоров родом варзужанин, тягла под ним салдацкого полчети и пол-полтрети обжи, а в той двор женат он, Бориска, в животы на салдаџкой жене на Феодорке во 166-м году, а муж ея первой Никифорко Савкин взят с тово жеребья в салдаты во 166-м году, сшел за себя, у нея ж Феодорки на жеребье с ней деверь ея Митрошка Карпов двенатцати лет, а записан был муж ея от отца, и отец ево умре». Итак, сразу после отбытия мужа (о смерти которого ничего не сказано, поэтому, скорее всего, он был жив) на службу, в том же 7166 (1558) г. Феодорка взяла к себе в мужья варзужанина Бориску Никифорова. С ними остался жить брат первого мужа (возможно, двоюродный, поскольку имел другое отчество) Митрошка. Через 7 лет в 1665 г. Бориска Никифоров хотя и числится главой семьи, но жеребей все же был записан за Феодоркой («...на жеребье с ней...»).

Другую отчасти сходную историю (хотя и менее поддающуюся однозначной трактовке) мы видим в дер. Жерлыгинской Заостровской вол. (л. 394 об.). Там жил Бориско Осипов, у которого был взят в 7162 г. в солдаты брат Карпушка, жена которого скиталась в мире. Интерес представляет продолжение, раскрывающее предысторию появления Бориски в этом дворе: «а как салдацкая опись была и они, Бориско и Карпушка в то время жили бобылями, а Бориско в тот двор женат в животы, а ис того двора прежнего жилца Якимка Терентьева взят в салдаты сын Антонко и в службе умре, а Якимко дома умре». Итак, перед нами ситуация вроде той, что сложилась с Бориской Никифоровым. Но тут появляется много сложностей, не позволяющих предложить единственную трактовку этой записи. Прежде всего, не совсем понятно, о какой именно «солдатской описи», во вре- 
мя которой пошел в службу сын прежнего владельца двора, идет речь. Год ее не обозначен. Мы можем предположить, что это была та же опись 7162 г., указанная в первой части записи (когда в службу пошел брат нового владельца), но это лишь предположение, основанное на том, что в ТСК всегда отмечался год солдатской описи. Не названа по имени и жена Бориски, очевидно потому, что в отличие от предыдущего указанного нами случая в Тарненской вол., она не являлась владелицей двора и тяглого жеребья. Им был Якимко, умерший позднее, но также неясно, когда именно. Непонятно и то, чьей женой была эта будущая жена Бориски: Якимки Терентьева или его сына Антонки, взятого в солдаты. Если она была женой Якимки и вышла за бобыля Бориску после смерти мужа, тогда это не является тем вариантом замужества солдатских жен, который мы исследуем. При иной трактовке получается, что во время солдатской описи в 7162 (1654) г. были взяты в службу женатый сын Якимки Терентьева Антонка, а также бобыль Карпушка Осипов. Сразу же после этого жена Антонки вышла замуж за брата Карпушки бобыля Бориску Осипова, который (после того как умер отец Антонки Якимка) был записан в этот двор.

Итак, перед нами раскрываются некоторые обстоятельства, при которых солдатки принимали нового мужа к себе во двор. Но во всех остальных случаях, исследованных нами, замуж выходили жены сыновей или младших братьев дворовладельцев. Значит, в основном именно женщина уходила в другой двор и в другую семью. Резонно думать, что это были бездетные солдатки. Вариант семейного устройства, при котором солдатская жена вышла замуж, а дети скитались или жили у родни, встречается всего три раза. В Литвиногорской вол. в дер. Седельниковская и Старухинская (л. 23-23 об.) двором владел Никифорко Максимов, «с ним брат родной Андрюшка дватцати лет, да от него ж Никифорка... с того ж тяглово жеребья взят в салдаты брат ево родной Федка женатой, сшел за себя, жена ево вышла замуж, а дети его, Федкины, Ивашко десяти лет и Коземко осми лет живут у него ж, Никифорка», то есть у деверя солдатки. В двух случаях солдатские дети скитались в мире, при том что солдатка вышла замуж. На л. 47 об. находим в Вахрушевской вол. в дер. Гусевской наемщика Федку Емельянова, жена которого вышла замуж, «а сын Гераско семи лет скитаетиа в мире». А на л. 355 в Пучюжской вол. в Петровском пр., в дер. Павловской жил «Худячко Зиновьев одинок», у которого в 7162 г. забрали в службу брата Ивашку, жена которого вышла замуж, а «сын Карпушка девяти лет скитаетиа в мире». Как видим, новые мужья солдаток не стремились брать в дом пасынков.

Результаты. Мы обследовали материал 67 волостей, описанных в ТСК. Количество деревень в каждой из них было различным. Оно колебалось от 7 (в небольших волостях типа Березницкой или Пянской) до 20 с лишним (в средних типа Кургоменскои или Троецкой) и даже доходило до 150 (в крупных волостях вроде Топсы). По числу дворов волости также были различны: для крупной волости это в среднем около 150 дворов, для средней и мелкой - примерно 50-70 дворов. Из этих 67 волостей ушли служить солдатскую службу, судя по ТСК, 430 женатых крестьян. На этом фоне 145 случаев (к 140 случаям, когда в ТСК не сказано о смерти первого мужа, прибавим 3 случая с определенным указанием того, что муж-солдат жив, и 2 случая, когда записана женитьба крестьянина на солдатке) выхода замуж солдатских жен могут считаться массовым явлением.

В 1665 г. в волостях, описанных в ТСК, из 430 жен-солдаток, мужья которых были в начале русско-польской войны (в 16541655 гг.) взяты в солдаты, женщины жили после этого у родственников в 121 случае, вышли вторично замуж в 166 случаях (причем только в 21 случае мы можем предполагать выход замуж после смерти первого мужа), скитались в мире 79, умерло 47 солдаток. Оставшиеся 17 случаев распределяются между немногочисленными в каждой группе вариантами, когда солдатки либо отделялись от родни мужа и жили своим двором, либо продавали мужнин жеребей, либо жили на дворе крестьян, за которых наемщиком пошел служить муж. Очевидно, что стандартной можно считать ситуацию, когда женщине, которая не находила помощи у родственников, приходилось выбирать между замужеством и нищен- 
В.Г. Вовина-Лебедева. «Жена его вышла замуж...»: к вопросу о судьбах солдатских жен в XVII в.

ством в миру. Можно предполагать, что и община была заинтересована в выдаче замуж солдаток как можно быстрее после ухода первого мужа в службу, и государство устраивал такой вариант. Во всяком случае, такое сожительство (или невенчанный брак) фиксировалось в ТСК и таким образом получало своего рода признание.

К сожалению, пока не удалось обнаружить хотя бы один случай, когда крестьянин, жена которого вышла замуж, значился бы в последующих государственных описаниях живым и вернувшимся. Мы не можем также определить судьбу вышедших замуж жен в случае возвращения прежнего мужа-солдата, так как при последующих описаниях, в частности при описании 1677/78 г., женщины не указывались. Тем не менее сравнительное исследование этого описания и описания 1665 г. по одним и тем же волостям является важной задачей, и нельзя пока исключать того, что в итоге такая работа может дать для нашей темы новый материал.

\section{СПИСОК ЛИТЕРАТУРЫ}

1. Андреев, А. И. Заметки к истории Русского Севера / А. И. Андреев // Летопись занятий Археографической комиссии за 1927-1928 годы. - Л. : Изд-во АН СССР, 1929. - Вып. 35. - С. 169-176.

2. Васильев, Ю. С. Материалы писцового делопроизводства по Важскому уезду XVI - первой половины XVII века: каталог / Ю. С. Васильев // Важский край: источниковедение, история, культура : материалы и исследования. - Вып. 3. - Вельск : Вельский краеведческий музей, 2006. - С. 135-156.

3. Вовина-Лебедева, В. Г. Государственные описания XVII - начала XVIII в. как источник для реконструкции жизни дворцовой волости (по материалам Кургомени) / В. Г. Вовина-Лебедева // Древняя Русь. Вопросы медиевистики. - 2017. - № 3 (69). C. 27-28.

4. Вовина-Лебедева, В. Г. Дворцовая волость Русского Севера в 1700-х годах / подгот. текста к печати, комментарии, вводная статья В. Г. Вовина-Лебедева // Новгородская земля, Санкт-Петербург и Швеция в XVII-XVIII вв. : сб. ст. к 100-летию со дня рождения Игоря Павловича Шаскольского. Тр. СПбИ РАН. Вып. 4 (20). - СПб. : Нестор-История, 2016. - C. 166-247.

5. Вовина-Лебедева, В. Г. Кургоменская волость в конце XVII - начале XVIII в. / В. Г. ВовинаЛебедева // Каргополь и Русский Север в истории и культуре России X-XXI вв. : материалы XIV Каргопольской науч. конф. - Каргополь : Каргопольский историко-архитектурный и художественный музей, 2018. - C. 82-88.

6. Малов, А. В. Первая служба Государева выборного полка Аггея Шепелева: Литовский поход 1658-1660 гг. / А. В. Малов // Известия Уральского государственного университета. - 2004. - № 33. C. $160-173$.

7. Малов, А. В. Московские выборные полки солдатского строя в начальный период своей истории / А. В. Малов. - М. : Древлехранилище, 2006. $-624 \mathrm{c}$.

8. Пушкарева, Н. Л. Женщины Древней Руси и Московского царства X-XVII вв. / Н. Л. Пушкарева. - СПб. : Изд-во Олега Абышко, 2017. - 448 с.

9. Тягольно-солдатская книга Важского уезда 1665 г. // Архив Санкт-Петербургского институга РАН. - Кол. 115. - Д. 309. - 500 л.

10. Щербинин, П. П. Военный фактор в повседневной жизни русской женщины в XVIII начале XX в. / П. П. Щербинин. - Тамбов : Юлис, 2004. $-508 \mathrm{c}$.

11. Щербинин, П. П. Солдатские жены в XVIII начале XX в.: опыт реконструкции социального статуса, правового положения, социокультурного облика, поведения и настроений / П. П. Щербинин // The Journal of Power Institutions in Post-Soviet Societies: Military and Security Structures in/and the Regions \&Women in/and the Military. - 2004. - Iss. 4/5. - Электрон. текстовые дан. - Режим доступа: http://www. pipss.org/documents493.html.

\section{REFERENCES}

1. Andreev A.I. Zametki k istorii Russkogo Severa [Notes to the History of the Russian North]. Letopis zanyatiy Arkheograficheskoy komissii za 1927-1928 gody [Annals of Studies of the Archaeographic Commission for 1927-1928]. Leningrad, Izd-vo AN SSSR, 1929, iss. 35, pp. 169-176.

2. Vasilyev Yu.S. Materialy pistsovogo deloproizvodstva po Vazhskomu uezdu XVI - pervoy poloviny XVII veka: catalog [Materials of Clerical Records in Vazhskiy Uyezd of the $16^{\text {th }}$ - First Half of the $17^{\text {th }}$ Century. Catalog]. Vazhskiy kray: istochnikovedenie, istoriya, kultura: materialy $i$ issledovaniya [Vazhskiy Krai: Source Study, History, Culture. Materials and Research]. Velsk, Velskiy kraevedcheskiy muzey, 2006, iss. 3, pp. 135-156.

3. Vovina-Lebedeva V.G. Gosudarstvennye opisaniya XVII - nachala XVIII v. kak istochnik dlya rekonstruktsii zhizni dvortsovoy volosti (po materialam Kurgomeni) [State Descriptions of the $17^{\text {th }}-$ Early $18^{\text {th }}$ Century as a Source for the Reconstruction of the 
Life of the Palace Volost (Based on the Materials of Kurgomen)]. Drevnyaya Rus. Voprosy medievistiki [Old Russia. The Questions of Middle Ages], 2017, no. 3 (69), pp. 27-28.

4. Vovina-Lebedeva V.G. Dvortsovaya volost Russkogo Severa v 1700-kh godakh [Palace Volost of the Russian North in the 1700s]. Novgorodskaya zemlya. Sankt-Peterburg i Shvetsiya $v$ XVIIXVIII vv.: sb. st. $k$ 100-letiyu so dnya rozhdeniya Igorya Pavlovicha Shaskolskogo. Tr. SPbI RAN. Vyp. 4 (20) [Novgorod Land, Saint Petersburg and Sweden in the $17^{\text {th }}-18^{\text {th }}$ Centuries. Collection of Articles for the $100^{\text {th }}$ Anniversary of Igor Pavlovich Shaskolsky. Works of Saint Petersburg Institute of History of the Russian Academy of Sciences. Iss. 4 (20)]. Saint Petersburg, Nestor-Istoriya Publ., 2016, pp. 166-247.

5. Vovina-Lebedeva V.G. Kurgomenskaya volost v kontse XVII - nachale XVIII v. [Kurgomen Volost in the Late $17^{\text {th }}-$ Early $18^{\text {th }}$ Century]. Kargopol $i$ Russkiy Sever $v$ istorii i kulture Rossii $X-X X I v v$.: materialy XIV Kargopolskoy nauch. konf. [Kargopol and the Russian North in the History and Culture of Russia of the $10^{\text {th }}-21^{\text {st }}$ Centuries. Proceedings of the $14^{\text {th }}$ Kargopol Scientific Conference]. Kargopol, Kargopolskiy istoriko-arkhitekturnyy i khudozhestvennyy muzey, 2018, pp. 82-88.

6. Malov A.V. Pervaya sluzhba Gosudareva vybornogo polka Aggeya Shepeleva: Litovskiy pokhod 1658-1660 gg. [The First Service of the Sovereign's Elective Regiment of Aggey Shepelev: Lithuanian Campaign of 1658-1660]. Izvestiya Uralskogo gosudarstvennogo universiteta, 2004, no. 33, pp. 160-173.
7. Malov A.V. Moskovskie vybornye polki soldatskogo stroya $v$ nachalnyy period svoey istorii [Moscow Elected Regiments of the Soldier System in the Initial Period of Its History]. Moscow, Drevlekhranilishche Publ., 2006. 624 p.

8. Pushkareva N.L. Zhenshchiny Drevney Rusi i Moskovskogo tsarstva X-XVII vv. [Women of Old Russia and the Moscow Tsardom of the $10^{\text {th }}-17^{\text {th }}$ Centuries]. Saint Petersburg, Izdatelstvo Olega Abyshko, 2017. 448 p.

9. Tyagolno-soldatskaya kniga Vazhskogo uezda $1665 \mathrm{~g}$. [Book on Taxes and Soldiers of 1665 in Vazhsky Uyezd]. Arkhiv Sankt-Peterburgskogo instituta RAN [Archive of Saint Petersburg Institute of the Russian Academy of Sciences], Col. 115, D. 309. 5001.

10. Shcherbinin P.P. Voennyy faktor $v$ povsednevnoy zhizni russkoy zhenshchiny $v$ XVIII nachale $X X v$. [Military Factor in the Everyday Life of a Russian Woman in the $18^{\text {th }}-$ Early $20^{\text {th }}$ Centuries]. Tambov, Yulis Publ., 2004. 508 p.

11. Sherbinin P.P. Soldatskie zheny v XVIII nachale XX v.: opyt rekonstruktsii sotsialnogo statusa, pravovogo polozheniya, sotsiokulturnogo oblika, povedeniya i nastroeniy [Soldiers' Wives in the $18^{\text {th }}-$ Early $20^{\text {th }}$ Century: Experience of Reconstructing Social Status, Legal Status, Socio-Cultural Appearance, Behavior and Sentiments]. The Journal of Power Institutions in Post-Soviet Societies: Military and Security Structures in/and the Regions \&Women in/ and the Military, 2004, iss. 4/5. URL: http://www.pipss. org/documents493.html.

\section{Information About the Author}

Varvara G. Vovina-Lebedeva, Doctor of Sciences (History), Leading Researcher, Saint Petersburg Institute of History of the Russian Academy of Sciences, Petrozavodskaya St., 7, 197110 Saint Petersburg, Russian Federation, Varvara_Vovina@mail.ru, https://orcid.org/0000-0003-1465-4139

\section{Информация об авторе}

Варвара Гелиевна Вовина-Лебедева, доктор исторических наук, ведущий научный сотрудник, Санкт-Петербургский институт истории Российской академии наук, ул. Петрозаводская, 7, 197110 г. Санкт-Петербург, Российская Федерация, Varvara_Vovina@mail.ru, https://orcid.org/0000-0003-1465-4139 